\title{
TECHNOLOGIES OF DIRECT ENERGY ACTION IN THE PROCESSES OF THE REMOVAL OF HOMOGENIC AND HETEROGENIC FOOD SYSTEMS
}

\author{
O. Burdo, I. Syrotyuk, Yu. Levtrinskaya \\ Odessa National Academy of Food Technologies \\ S. Terziev \\ PJSC “Annie Foods"
}

\begin{tabular}{l}
\multicolumn{1}{c}{ Key words: } \\
Energy efficiency \\
Food technologies \\
Capillary structures \\
Microwave radiation \\
\hline
\end{tabular}

Article history:

Received 07.09.2018

Received in revised form

25.09.2018

Accepted 16.10.2018

Corresponding author:

O. Burdo

E-mail:

npnuht@ukr.net

\begin{abstract}
This article presents the results of research on the technologies of directed energy action when concentrating extracts of medicinal herbs and coffee, juices. The classification of gradient and non-gradient methods of energy supply, technologies of directed energy action were deepened and expanded. The mathematical models describing the mechanism of combined nanoparticle and macro transfer of moisture from the fibrous capillary structure of plant material, the peculiarities of formation of the target component flow under the influence of the microwave field were presented. The diagrams were presented and the principle of the developed experimental stand for dewatering was described. The peculiarities of this stand are the use of a microwave generator as a source of energy, the creation of vacuum conditions in the chamber with the help of a vacuum pump, which greatly reduces the operating temperatures. Due to the use of the microcontroller an automated collection of information on changes in temperature and mass of condensate was organized. The stand design allows to select heterogeneous and dispersed food systems as well as homogeneous as experimental objects such as juices, extracts, crushed fruit, vegetables, products of animal origin. A number of experimental studies have been carried out using a variety of raw materials. Data on the dewatering kinetics, temperature changes in the process of dehydration were obtained. When concentrating heterogeneous liquid systems, high concentration values reach up to $92^{\circ}$ brix. Such a concentrate can not be obtained from existing vacuum evaporators, because of the design features or through the volumetric supply of energy to the raw material. The selective action on the water and alcohol molecules is also observed in the results for capillary structures, such as coffee sludge. The sludge of coffee has a moisture content of about $80 \%$ after unloading from the extractors, it is necessary to dehydrate it for further processing. In the presented installation, the rate of dewatering the sludge is 2.5 times higher than the rate of dehydration of heterogeneous systems.
\end{abstract}

DOI: $10.24263 / 2225-2924-2018-24-5-13$ 


\title{
ТЕХНОЛОГІЇ НАПРАВЛЕНОЇ ЕНЕРГЕТИЧНОї ДІЇ У ПРОЦЕСАХ ЗНЕВОДНЕННЯ ГОМОГЕННИХ I ГЕТЕРОГЕННИХ ХАРЧОВИХ СИСТЕМ
}

\author{
О.Г. Бурдо, І.В. Сиротюк, Ю.О. Левтринська \\ Одеська національна академія харчових технологій \\ С.Г. Терзієв \\ ПАО «Енні Фудз»
}

У статті наведено результати досліджень технологій направленої енергетичної дії при концентруванні екстрактів лікарських трав $i$ кави, соків. Поглиблено та розщирено класифікацію градієнтних $і$ безградієнтних способів підведення енергії, технологій направленої енергетичної дії. Представлено математичні моделі, що описують механізм комбінованого нанота макропереносу вологи з волокнистої капілярної структури рослинної сировини, визначено особливості формування потоку иільового компоненту при впливі мікрохвильового поля. Розроблено схеми та описано приниип дії експериментального стенду для зневоднення. Особливостями иьього стенду $\epsilon$ використання як джерела енергії мікрохвильового генератора, створення умов розрідження в камері за допомогою вакуумного насоса, щь значно знижує робочі температури. Завдяки використанню мікроконтролера організовано автоматизований збір інформації про зміну температур та масу конденсату. Конструкиія стенду дає змогу обирати як експериментальні об'єкти гетерогенні та дисперсні харчові системи, а також і гомогенні (соки, екстракти, подрібнені фрукти, овочі, продукти тваринного походження). Проведено ряд експериментальних досліджень з використанням різноманітної сировини. Отримано дані про кінетику зневоднення, зміну температур у процесі зневоднення. При концентруванні гетерогенних рідких систем досягнуто високих значень концентрації- до $92^{\circ} \mathrm{brix}$. Через особливості конструкиії та об'ємне підведення енергії до сировини такий кониентрат неможливо отримати в існуючих вакуум-випарних апаратах. Вибіркова дія на молекули води та спиртів простежується $і$ в результатах для капілярних структур, таких як илам кави. Шлам кави має вологість близько 80\% після вивантаження з екстракторів, для його зберігання 3 метою подальшої переробки необхідне зневоднення. У представленій установиі швидкість зневоднення шламу у 2,5 раза вища за швидкість зневоднення гетерогенних систем.

Ключові слова: енергоефективність, харчові технології, капілярні структури, мікрохвильове випромінювання.

Постановка проблеми. Проблема ефективного використання та раціонального підходу до розподілення ресурсів вкрай актуальна для людства. Порівняти іï можна з іншою проблемою - нестачею продуктів харчування, що 
спричиняє продовольчу кризу в багатьох країнах. Проблематика викликана як стрімким розвитком технологій, урбанізацією, що вимагають все більшої кількості енерговитрат, так і проблемою вичерпності паливно-енергетичних ресурсів (ПЕР), які нерівномірно розподілені у світі. Деякі країни мають більші запаси ПЕР, що $є$ потужним важелем впливу на економіку та навіть на політичний курс розвитку менш енергозабезпечених країн. Такий ефект відчутний в усьому світі, тому пошук шляхів зниження витрат енергії $є$ принциповим питанням, що визначає економічну та політичну стабільність [1-4]. Відсутність системного підходу до дослідження енерготехнологічних проблем, досвіду у вирішенні завдань ефективного використання ресурсів можуть стати причиною економічної кризи в країні [5].

У пропонованій статті поставлено і вирішується завдання організації технологій направленої енергетичної дії (НЕД). Це є напрямком, якому присвячено ряд наукових праць авторів, де досліджуються енергоефективні технології переробки харчової сировини, такі як сушіння, екстрагування, концентрування харчових розчинів, технології інактивації мікроорганізмів. У цьому дослідженні вперше доведено та показано, що енергетика $\epsilon$ не тільки характеристикою, основним результатом технології, а й інструментом організації технології, засобом управління кінетикою процесів переносу в елементах різних систем. Спрямоване, селективне підведення енергії до тих елементів сировини, які вимагають енергетичного впливу, є інноваційним засобом організації процесів масоперенесення. Така організація процесу дасть змогу зберегти термолабільні елементи сировини, які повинні мінімально піддаватися енергетичному впливу. Особливу увагу слід приділяти мікро- і нанорозмірним структурам сировини. Ці елементи в традиційних технологіях практично не розглядаються, грунтовних досліджень цього напряму недостатньо. У цьому дослідженні визначено подальші перспективи НЕД-технологій у харчовій і фармацевтичній промисловостях.

Аналіз останніх досліджень і публікацій. Сучасні дослідження розкривають нові методи системного підходу до вирішення проблем забезпечення енергією [2-3]. Свропейські та азіатські вчені активно розвивають інноваційні теплотехнології [4], впроваджують альтернативні джерела енергії, теплові насоси [5], системи теплоутілізації [6] тощо. Зважаючи на високу енерговитратність харчової індустрії, ці підходи вкрай актуальні для галузі. Традиційні підходи регулювання енерговитрат (такі як енергозбереження) неактуальні для харчової промисловості. Насамперед це пов'язано зі зростанням попиту на продукти харчування та підвищення вимог до їхньої якості. Через процеси глобалізації й урбанізації змінюються звичні моделі забезпечення населення продуктами харчування, більшість підприємств переноситься за межі міст і великих населених пунктів, що підвищує витрати на транспортування продукції. Це сприяє зростанню потреби та зацікавленості у зневодненні харчових продуктів, виробництві харчових концентратів. Впровадження технологій зневоднення викликає ряд інших проблем екологічні, додаткові витрати енергії, погіршення якості продуктів через термічну обробку тощо [1]. 
Шляхом вирішення цих проблем має бути новий принцип передачі енергії, комбінування впливів на процеси перенесення, формування рушійних сил за іншими принципами [7]. Аналіз теплотехнологій [8-11], що вимагають колосальних витрат енергії на фазові переходи, вилучення цільових компонентів, сушіння, показує, що розвиток технологій вимагає спрямованого, селективного підведення енергії до тих елементів сировини, які вимагають енергетичного впливу. За таких умов можливо зберігати термолабільні компоненти, видаляючи безпосередньо вологу, зберігаючи якість харчових продуктів.

Численні дослідження процесів на рівні капіляра показують, що процеси мікрокінетики важко піддаються дослідженню, немає інформації про вплив таких факторів, як кількість мікрохвильової енергії, необхідної для утворення потоку з капіляра, впливу безпосередньо мікрохвиль на термолабільні компоненти, пароутворення при впливі мікрохвильового випромінювання. Згідно з гіпотезою, яку ми висуваємо у цьому дослідженні, адресний спрямований вплив енергії на вологу в харчовому продукті дасть змогу інтенсифікувати процеси зневоднення, вирішити проблему збереження якості харчового продукту.

Мета статті: дослідження технологій направленої енергетичної дії, підтвердження виникнення потужного потоку компонентів при екстрагуванні та вологи при випарюванні під дією направленого потоку енергії.

Матеріали і методи. Класифікаиія НЕД-технологій. НЕД-технології - це технології спрямованої, селективної дії на елементи сировини і біологічні об'єкти. НЕД-нанотехнології відрізняються тим, що напрямок енергетичної дії - наномасштабні об'єкти, мікро- і наномасштабні структури. I в першому, і в другому випадках завданням селективного енергетичного впливу $\epsilon$ управління полями, визначення напрямків силових впливів слабких полів, організація потоку з мікро- і нанокапілярної структури, формування складу цих потоків, напрямку силових впливів на оболонки клітинної структури мікробіологічних об’єктів тощо [7].

Для харчових систем зниження кількості спожитої енергії не тільки підвищить енергетичний ККД процесу і знизить собівартість продукту, але й зменшить рівень термічного впливу на продукт. Це призведе до збереження термолабільних і біологічно активних компонентів харчової сировини. Наприклад, харчові продукти і кулінарні вироби, отримані за НЕД, відповідатимуть вимогам функціонального харчування.

Загалом, є два напрямки керування потоками енергії [12]. Перший (градієнтний принцип) - це доставка енергії до поверхні сировини за допомогою високоефективних тепловодів. Другий (безградієнтний принцип) - це локальна доставка енергії безпосередньо до вологи в об'ємі сировини. Розглянемо класифікацію цих напрямків (рис. 1,2 ).

Класифікація (рис. 1) відображає засоби реалізації принципів, їх конструктивні відмінності, переваги та можливості конструкцій. Застосування теплових труб, гравітаційних і ротаційних термосифонів досить широко розглянуто в ЕСУ, ТТв АПК. Значно менше використовуються автономні двофазні системи, але їхні перспективи обгрунтовані [7]. 


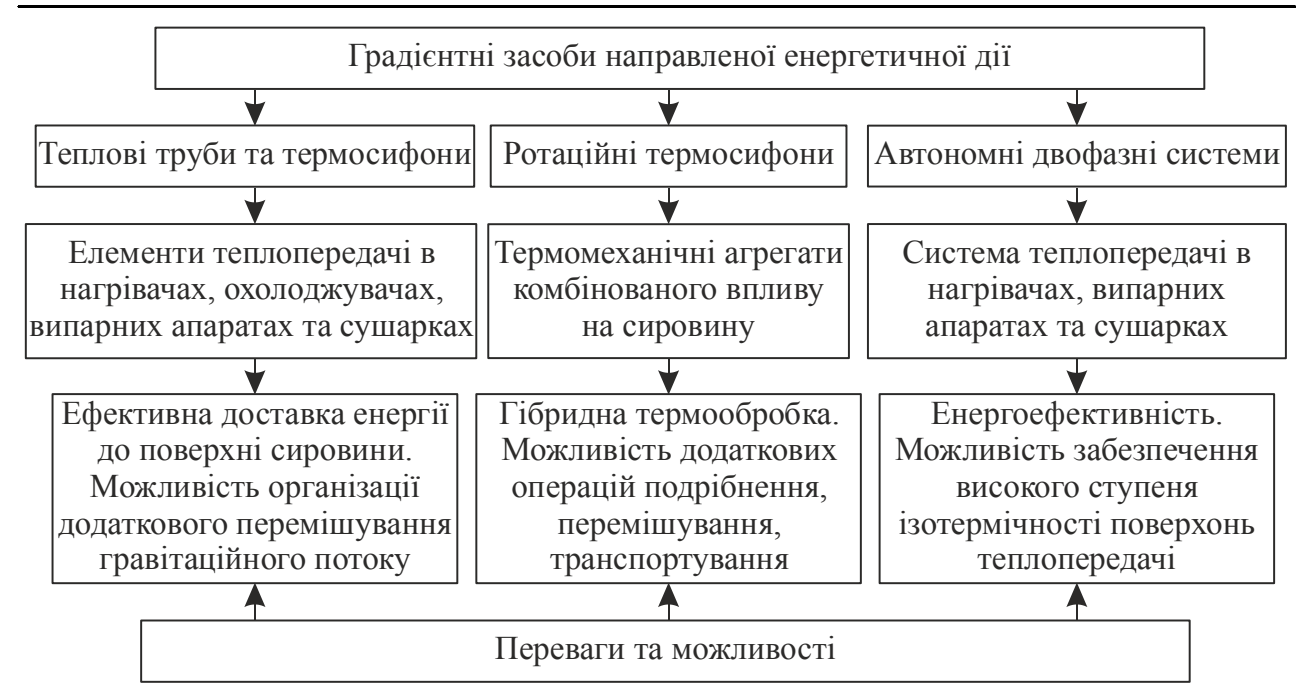

Рис. 1. Класифікація градіснтних принципів направленої енергетичної дії

Революційним напрямком можна вважати безградієнтні принципи направленої енергетичної дії (рис. 2).

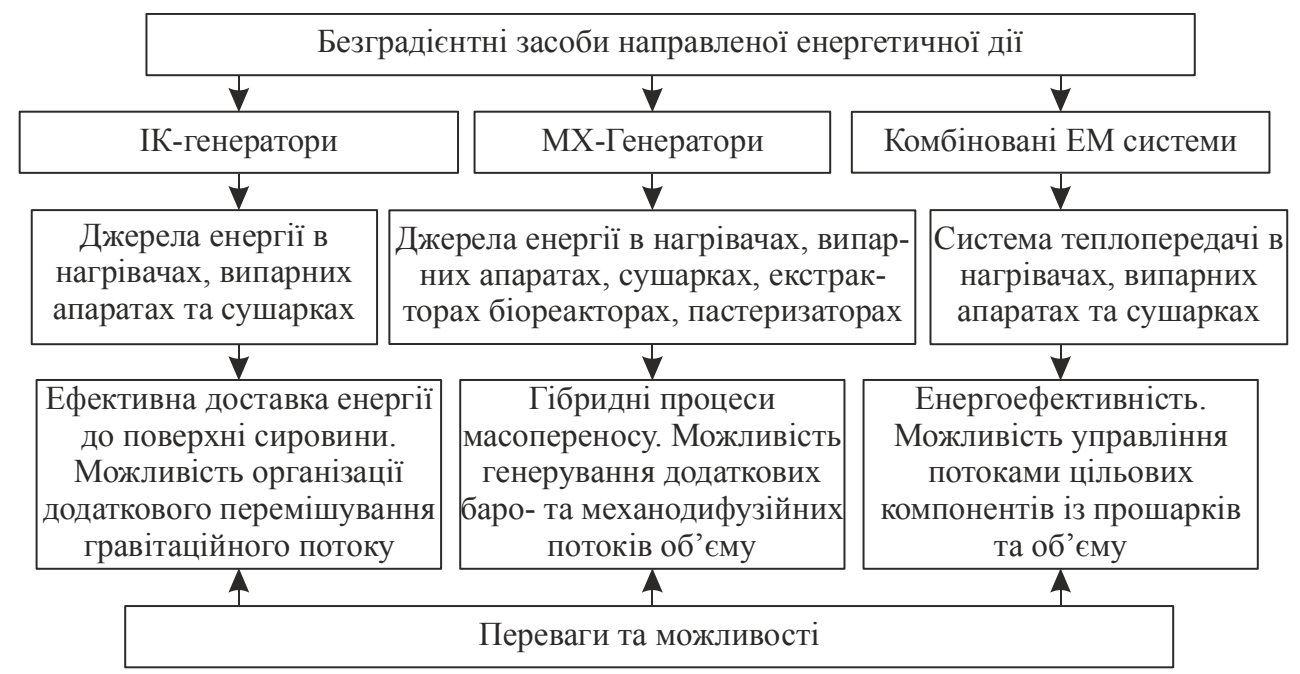

Рис. 2. Класифікація безградієнтних принципів направленої енергетичної дії

Наведені принципи (рис. 2) мають перспективи в організації масообмінних процесів: сушіння, екстрагування, кристалізації. Вони здатні вирішувати науково-технічні суперечності, що стосуються переробки рослинної сировини.

Ефективність харчових технологій (продуктивність, питома енергоємність, якість готового продукту, ступінь вилучення цінних компонентів сировини тощо) значною мірою визначається можливостями впливів на оболонки клітин, мікроорганізми, пори, капіляри тощо. Технології НЕД - спосіб знайти ефективні рішення, підходи для локальних дій, спрямованих на інтенсивні, 
низькоенергоємні операції з харчовою сировиною і навіть 3 окремими нанорозмірними елементами цієї сировини. Важливим є створення фундаментальних основ еволюційних нанометричних явищ і процесів. Враховуючи теперішні тенденції розвитку технологій [7], можна прогнозувати розвиток процесів НЕД-технологій (рис. 3).

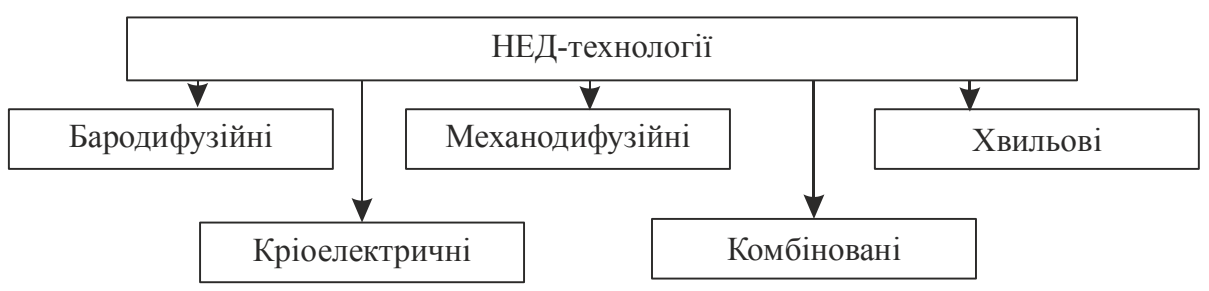

Рис. 3. Класифікація процесів НЕД- технологій

Нанотехнологічні прийоми при кріорозділенні водних розчинів знайдуть застосування при низькотемпературному концентруванні соків, екстрактів, виноматеріалів та інших водних розчинів, демінералізації води (в тому числі при отриманні води глибокого очищення), вирощуванні кристалів льоду і солей [7]. Хвильові та механодифузійні технології можуть стати основою нових ефектів при масопереносі [7]. Розглянемо детальніше бародифузійні ефекти в капіляропористих системах.

Механізм і модель бародифузіі. Зважаючи на термодинамічну схему нанопроцесів [7], механізм комбінованого нано- та макропереносу вологи (та інших компонентів) з волокнистої структури до потоку пояснюється схемою (рис. 4).

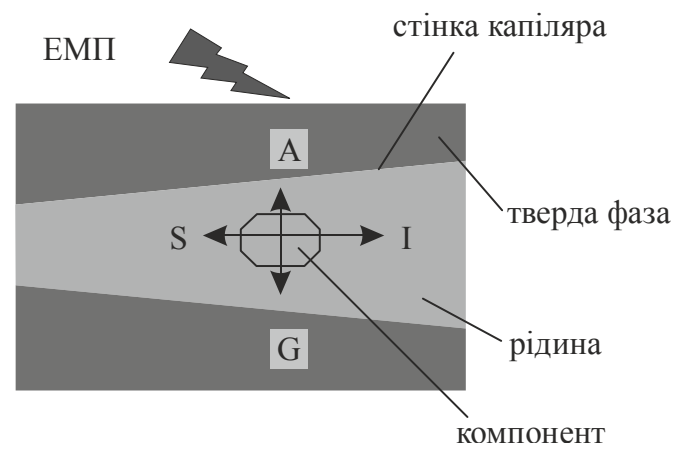

Рис. 4. Баланс сил, що діють на компонент у міжклітинному просторі

Розглянемо окремий компонент у капілярі сировини (рис. 4). На компонент діють сили: А — взаємодії з поверхнею капіляра; I - інерції потоку; $\mathrm{G}$ тяжіння; S - в'язкості. Баланс дії цих сил визначить, у якому напрямку і 3 якою швидкістю буде рухатись компонент.

Завданням інтенсифікації процесів масоперенесення $є$ ініціювання потоку I (рис. 4). Інші сили за схемою (рис. 4) гальмують процес. За рівнянням Фіка нестаціонарне поле концентрацій має вигляд: 


$$
\frac{\partial C}{\partial \tau}=D \frac{\partial^{2} C}{\partial Z^{2}}+\frac{\partial C}{\partial Z} W_{Z}
$$

Перший доданок в (1) характеризує суто дифузійний перенос, процес традиційно інерційний. Запропонована в дослідженні концепція спирається на потенційні можливості другого доданку в (1). Це зміни поля концентрацій, зумовлені виходом концентрованого розчину з капіляра зі швидкістю $w$, величина якої залежить від значення стрибка тиску $\Delta P$ з (2). Зв'язок між цими параметрами визначається з рівняння гідравліки капілярної системи 3 довжиною каналів (1), їх діаметром $(d)$, коефіцієнта тертя $(\lambda)$ і суми місцевих

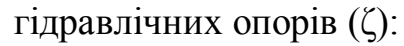

$$
\Delta P=\frac{\rho w^{2}}{2}\left[\frac{\lambda l}{d}+\sum \zeta\right]+\rho g l+\frac{\sigma}{d} .
$$

При використанні електромагнітного поля (рис. 4) в капілярі має місце

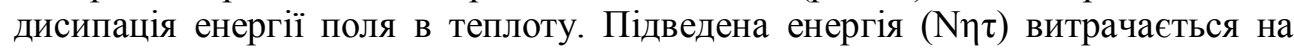
підвищення внутрішньої енергії при зміні теплоємності, переведення води в пару. В результаті - підвищення тиску в капілярі. Причому це зростання тиску може мати вибуховий характер через малий об'єм рідини в капілярі і концентрації енергії:

$$
P(\tau)=P a+\Delta P .
$$

Саме цей стрибок тиску й викликає бародифузію. При цьому суттєві зміни відбудуться у формуванні поля концентрацій цільових компонентів у системі.

Визначальним фактором при виникненні бародифузії $\epsilon$ температура в локальній точці об'єму сировини. Нестаціонарне поле температур 3 урахуванням дії ЕМП визначається за такою формулою:

$$
\frac{\partial t_{1}}{\partial \tau}=a_{1}\left(\frac{\partial^{2} t_{1}}{\partial r^{2}}+\frac{1}{r} \frac{\partial t_{1}}{\partial r}+\frac{1}{r^{2}} \frac{\partial^{2} t_{1}}{\partial \phi^{2}}+\frac{\partial^{2} t_{1}}{\partial z^{2}}\right)+\frac{N \eta}{V_{1} c_{1 V} \rho_{1}} .
$$

Вплив ЕМП виражається в (4) як дія внутрішнього джерела енергії потужністю $(N)$ і з ККД ( $)$.

У співвідношеннях (1)-(4): $c-$ питома теплоємність; $\lambda-$ коефіцієнт теплопровідності; $a-$ коефіцієнт температуропровідності; $\sigma-$ коефіцієнт поверхневого натягу; $\tau$ - час роботи; $z, r, \varphi$ - координати.

Наукові гіпотези апробовано при випробуваннях обладнання, що реалізує відповідні засоби НЕД технологій.

Інноваційне обладнання за принципом направленої енергетичної дії. Проведено стендові дослідження вакуумної камери для зневоднення сировини (рис. 5).

Парові обсяги робочої камери і конденсатора 3'єднані паропроводом, контроль вакууму в системі проводиться зразковим вакуумметром. Підведення електромагнітної енергії здійснюється блоком силової електроніки за командами блоку управління, який містить таймер і регулятор потужності. Водоохолоджувач складається з парокомпресорної холодильної машини, ємності 3 
охолоджувальної водою, регулятора температури води і циркуляційного насоса, який забезпечує подачу холодної води в конденсатор (5). Стенд комп’ютеризований, поточна інформація від електронних ваг, вимірювача температури пари, що виходить, і продукту у випарній камері через інтерфейс надходить, реєструється і обробляється процесором. У стенді використовувалися електронні ваги типу TBE-0,21-0,01 і датчики температур типу Dallas DS 18b20. Інформація збиралася на ноутбук або планшет CHUWI CW1506. Розроблена програма передбачала відображення на екрані дисплея термограм, убутку вологи з камери і миттєві значення швидкості видалення вологи (\% на хвилину).

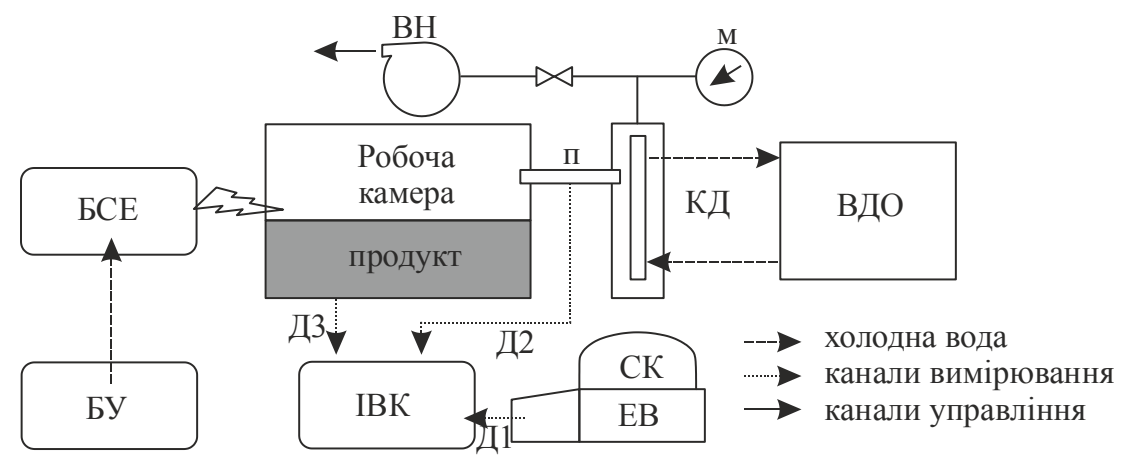

Рис. 5. Стенд для досліджень процесів зневоднення у мікрохвильовому полі

Результати експериментальних досліджень та їхнє обговорення. Для досліджень впливу мікрохвильового поля на харчову сировину були обрані продукти з різними властивостями, в тому числі й термолабільні (табл. 1).

Таблиия 1. Об’єкти експериментальних досліджень

\begin{tabular}{|c|c|c|}
\hline Продукт & Тип & Структура \\
\hline Сік ехінацеї & $\begin{array}{c}\text { ЛРС (лікарська рослинна } \\
\text { сировина) }\end{array}$ & $\begin{array}{c}\text { Рідка гомогенна система } \\
\text { (РГС) }\end{array}$ \\
\hline Шлам кави & Спиртова система & $\begin{array}{c}\text { Дисперсна гетеротропна } \\
\text { композиція (ДГК) }\end{array}$ \\
\hline Екстракт масла кави & Спиртовий розчин & Рідка гетерогенна композиція \\
\hline Морепродукти (мідії) & $\begin{array}{c}\text { Харчовий продукт } \\
\text { тваринного походження }\end{array}$ & Тверді фракції та вода \\
\hline Томатна паста & $\begin{array}{c}\text { Харчовий продукт } \\
\text { рослинного походження } \\
\text { Харчовий продукт } \\
\text { рослинного походження }\end{array}$ & Рідка гетерогенна структура \\
\hline Гранатовий сік & \multicolumn{2}{|c}{} \\
\hline
\end{tabular}

У дослідах реєструвалися: споживана потужність $(N)$, тиск у камері $(P)$, температура продукту $(T)$ і паропродуктивність $(W)$. Поточні значення $W$ визначалися за показаннями електронних ваг (за масою конденсату в збірнику). Завдяки цьому з високою точністю визначався вихід пари. Робочі температури не перевищували $50^{\circ} \mathrm{C}$. Типові залежності для чотирьох видів продукту наведені на рис. 6. 


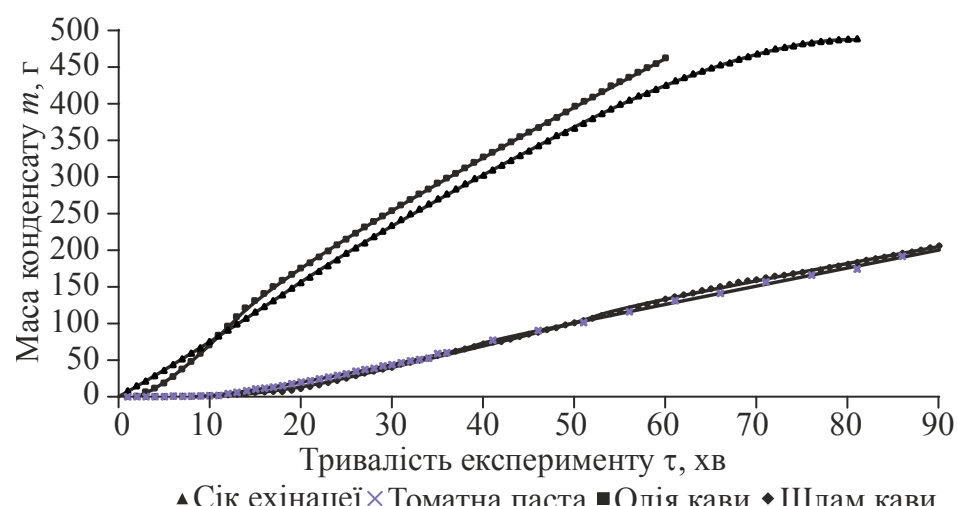

Рис. 6. Зміна маси конденсату на виході з МВА

Результати експерименту дали змогу визначити швидкість видалення вологи, зміна якої показано на рис. 7.

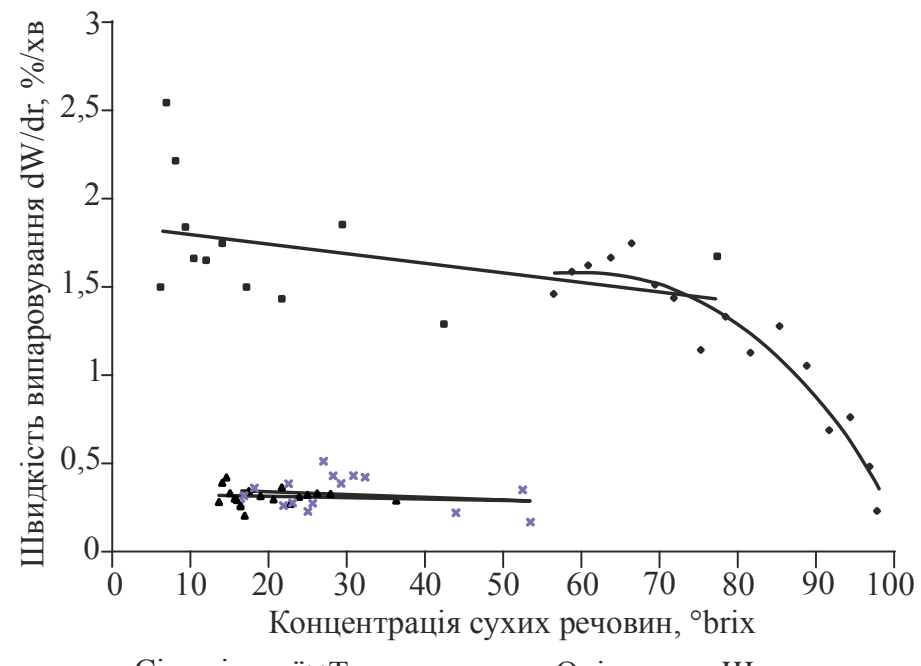

$\triangle$ Сік ехінацеї× Томатна паста $\bullet$ Олія кави -Шлам кави

Рис. 7. Лінії швидкості пароутворення у МВА

За результатами аналізу відповідності швидкості випаровування і концентрації продукту в апараті побудована залежність, яка показала, що швидкість видалення вологи в вакуумному МХ апараті практично постійна.

\section{Висновки}

Аналіз результатів дослідів дає змогу зробити такі вистновки:

- швидкість випаровування в МВА практично постійна (незначні флуктуації можна пояснити похибкою експерименту);

- досягнуті високі значення концентрацій продукту (до 92ºrix);

- кавовий шлам на виході практично не містив рідкої фази;

- вплив об'єму рідини в продукті помічається після концентрацій більше $80^{\circ}$ brix; 
- спиртовмісні системи характеризуються швидкістю випарювання в рази вищою, ніж ті, що містять воду.

\section{Література}

1. Gabor D., Colombo U., King A. S. Beyond the age of waste: a report to the Club of Rome. Elsevier, 2016. 258 p.

2. Balin B.E., Akan D.M. EKC hypothesis and the effect of innovation: A panel data analysis. Journal of Business Economics and Finance. 2015. T. 4. No. 1. P. 81-91.

3. Ul'ev L.M., Vasil'ev M.A. Heat and power integration of processes for the refinement of coking products. Theoretical Foundations of Chemical Engineering. 2015. T. 49. No. 5. C. $676-687$.

4. Atamanyuk, V., Huzova, I., \& Gnativ, Z. Study of diffusion processes in pumpkin particles during candied fruits production. Харчова наука та технологія. 2017. No. 11(4). С. 21-28.

5. Шит М.Л. и др. Многотемпературный тепловой насос с каскадным включением компрессоров. Проблемы региональной энергетики. 2017. № 2(34). С. 91—97.

6. Smirnov H. F., Zykov A. V., Reznichenko D. N. The determination of energy source optimal parameters for vacuum evaporation. Наукові праці ОНАХТ. 2017. Т. 80. o. 1. С. 133-137.

7. Бурдо О.Г. и др. Технологии селективного подвода энергии при выпаривании пищевых растворов. Проблемы региональной энергетики. 2017. № 1. С. 100-109.

8. Чуешов В.И., Гладух Е.В., Сайко И.В., Ляпунова О.А., Сичкарь А.А., Крутских Т.В., Рубан Е.А., Черняев С.В. Технология лекарств промышленного производства: учебник для студ. высш. учеб. завед.: перевод с укр. Яз. : в 2 ч. Ч. 1; Винница: Новая Книга, 2014. $696 \mathrm{c}$.

9. Боровкова Э.В., Давыдов И.Б., Пантюхина Е.В. Анализ недостатков и путей модернизации выпарных аппаратов. Известия Тульского государственного университета. Технические науки. 2018. № 2. С. 331-337.

10. Ащеулов А.С. Исследование процессов выпаривания настоев черноплодной рябины. Политематический сетевой электронный научный журнал Кубанского государственного аграрного университета. 2017. № 126. С. 131-140.

11. Cortes-Rodríguez E.F., Fukushima N.A., Palacios-Bereche R., Ensinas A.V., \& Nebra, S.A. Vinasse concentration and juice evaporation system integrated to the conventional ethanol production process from sugarcane-Heat integration and impacts in cogeneration system . Renewable Energy. 2018. T. 115. C. 474-488.

12. Burdo O.G., Bandura V.N., Levtrinskaya Y.O. Electrotechnologies of Targeted Energy Delivery in the Processing of Food Raw Materials. Surface Engineering and Applied Electrochemistry. 2018. T. 54. No. 2. C. 210-218. 